\title{
Analysis of Hydro-Morphometric of Flash Flood Hazard Map of Wadi Gharandal Basin, Southwestern Sinai Area, Egypt, Using GIS and RS
}

\author{
Mohamed Fouad Abd El-Aziz*
}

\begin{abstract}
The main object of the present study is to assess and produce flash flood hazard map to Wadi Gharandal based on the morphometric analysis with the aid of the techniques Remote sensing (RS) and geographic information system (GIS) ASTER DEM data are used to extract the stream network to assess the morphometric parametric and to make risk zone map of the study area. (GIS) and (RS) have been utilized for the morphometric analysis of wadi Gharandal basin southwestern Sinai, Egypt. Several morphometric parameters have been computed and analyzed, such as, circularity ratio, elongation ratio, form factor ratio, stream frequency and bifurcation ratio. Impacts of morphometric parameters on flash flood characteristics have been also investigated. Wadi Gharandal is divided into eighteen relatively large sub-basin, nine of them have high susceptibility for flooding, six have medium susceptibility and about three have low susceptibility for flooding. [Bul. Soc. Géog. d'Égypte, 2018, 91: 67-87]
\end{abstract}

Key Words: GIS, RS, ASTER, DEM, Hydro-Morphometric parameters.

\section{Introduction}

One of the main objects of the present study is using the powerful of a GIS tool to produce a map showing the pre-development flood risk potential of the Wadi Gharandal basin. The drainage basin analysis is important in any hydrological investigation like assessment of groundwater potential and management. The morphometric analysis of drainage basin carried out by Horton, (1945) Strahler (1952) and others is based on the fact that for the given conditions of lithology, climate, rainfall and other relevant parameters of the basin the river network, the slope and the surface relief tend to reach a steady state in which the morphology is adjusted to transmit the sediments and excess flow produced.

The present paper describes the drainage characteristics of Wadi Gharandal basin obtained through RS and GIS techniques as abasis of morphometric analysis. It is felt that the study will be useful to understand hydrological behavior of the basin. The remotely sensed data is geometrically rectified with respect to the studied Egyptian civil survey Authority topographical maps at scale 1:50000 using ENVI 7.4 software.

\footnotetext{
* Geography Department, Faculty of Arts, Arish University, Egypt.
} 


\section{Study Area}

The study area is located in the southwestern Sinai Egypt. It is bounded from the West by the Gulf of Suez and from the East by Wadi Al-Arish and Wadi Wardan, from the north by Wadi Wardan watershed and from the south by wadi al Hamr watershed (Figure 1). Wadi Gharandal basin is elongated and covers an area of about $1261.1 \mathrm{~km}^{2}$, and drains to the Gulf of Suez at about $24 \mathrm{~km}$ to the north of Abu zanima Town.

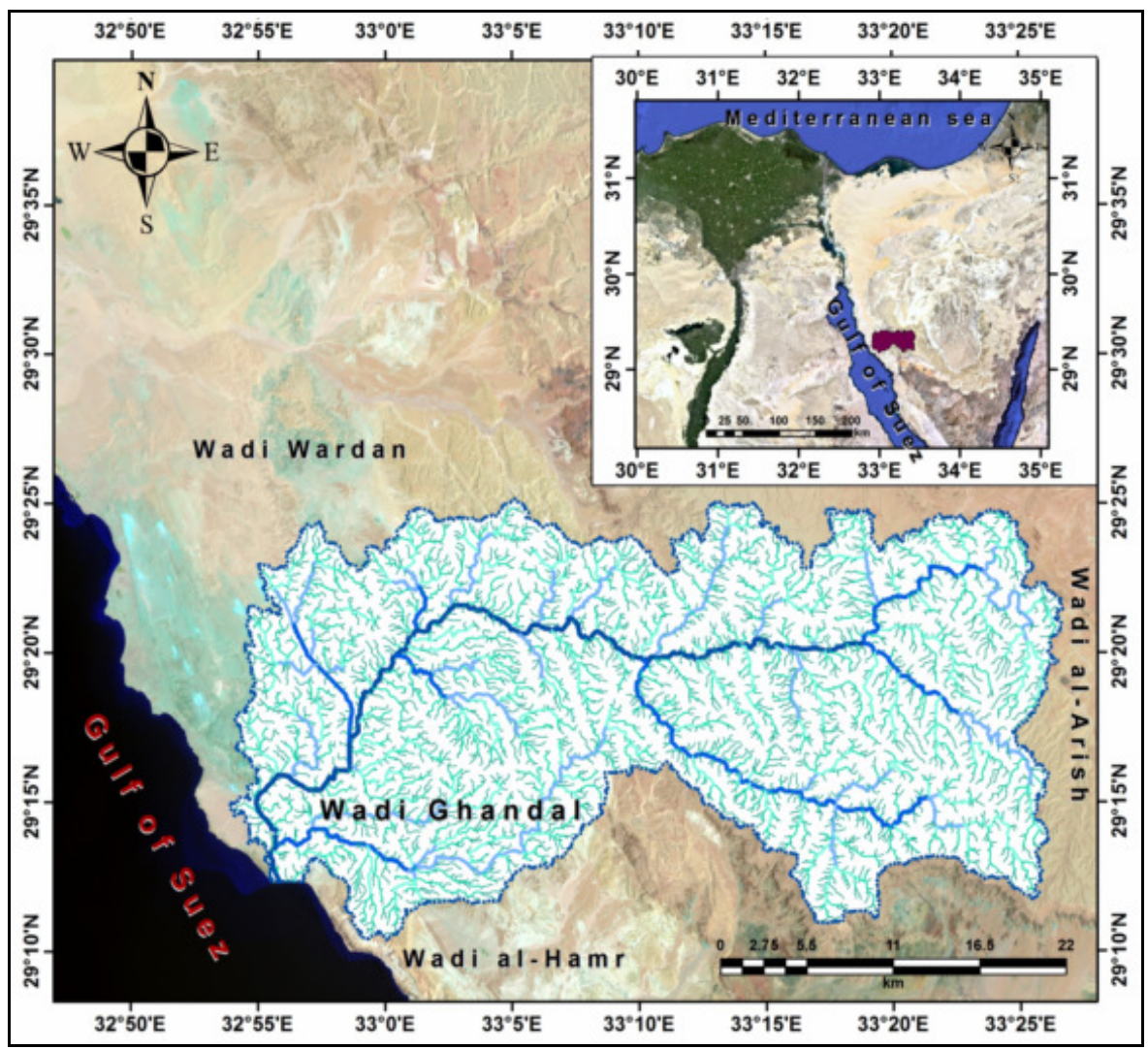

Figure 1. The Study area.

\section{Methodology}

The present study is based on four types of data set, which ara as follows. (i) topographic map (scale 1:50.000) (ii) Geological maps (scale: 1:100.000). (iii) Aerial-photos (scale: 1:33.000). (iv) Satellite images (Landsat 7 ETM, 2000) (scale: 1:400000). All primary data were imported in a Geographical Information System in environment to produce different GIS overlays and to compute the different areal and liner morph-hydrologic 
parametrsy the drainage basin and network. There are 3 meteorological stations in and around the study area. Their climatic data recorded from 1934 up to 2016.

\section{Physical Characteristics of The study Area Geological Study Area:}

Wadi Gharandal basin is covered by basement rocks. It consists of igneous and metamorphic rocks, forming high areas which are deeply dissected by numerous narrow and long wadies sbounded by steep cliffs forming high mountains with extended flat topped plateaus and steep slopes. The different rock units are highly affected by several faults and joints with different trends and densities (Figure 2).

The cretaceous sequence is classified into: The Wata Formation which deposited above the Raha Formation. The Matulla Formation, which overlies the Wata formation. Plate (1) consists mainly of limestones, marbles commonly alternating with shales, sandstones, shaley limestones and siliceous limestones. This Upper Cretaceous sequence is topped by the Sudr Formation that is composed mainly of chalk, partly changing to marls or argillaceous to crystalline limestone. The Upper Cretaceous sequence is unconformably overlain by calcareous Eocene sediments (limestone, chert, marl and shale) (Anwar, 2009, p. 84). The Miocene sequence exposed at the study area is classified into three main groups: (upper Miocene) South charib Formation and the Middle Miocene Hammah firawn Formation, Balaim Formation, Karim Formation (Egyptian General Petroleum Corporation, EGPC, 1964; Gawad et al., 1986) and the lower Rudays Nuknl Formations with extrusive basaltic rocks. The Eocene sequence is classified into five formations; the Minya Formation and the wasit (Lower Eocene), Samalut Formation (LowerMiddle Eocene) and the Tankah Formation, atyyaban Formation (Upper Eocene). The Quaternary deposits are cover by the stmean courses and flood plainarea (Plate 2).

\section{Climatic Conditions}

The climatic conditions of the Sinai Peninsula are similar to those, which characterize desert areas in other parts of the world. They include extreme aridity, long hot and rainless summer months and a mild winter. During the winter months, some areas of Sinai experience brief but intensive rainfall that makes wadi beds overflow and sometimes cause severe flash floods damaging the roadways and, sometimes, human lives (JICA, 1999, p. 65). The climatic data from 1980 to 2016 of three metorological stations around the study area are avalabile. 


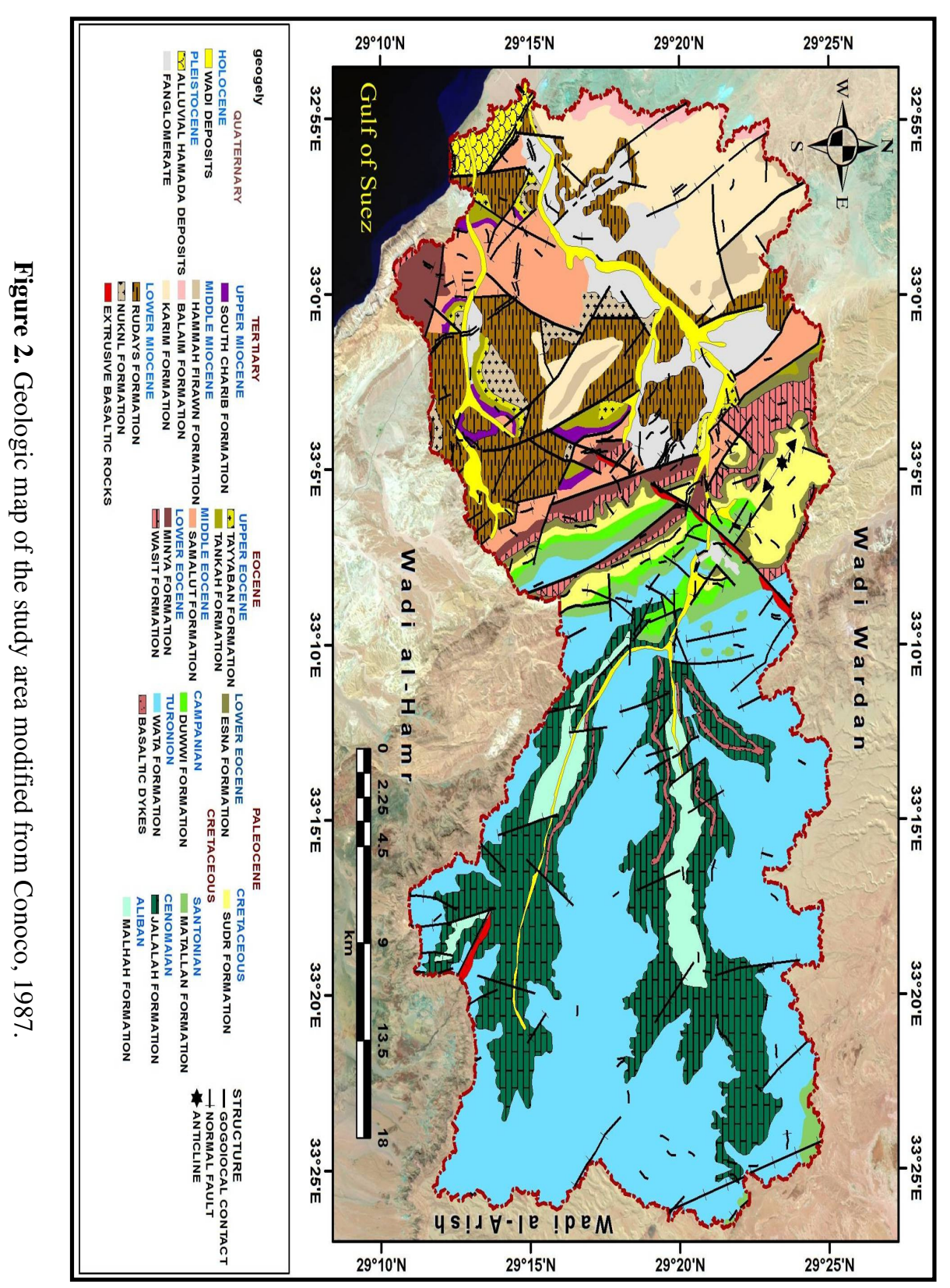




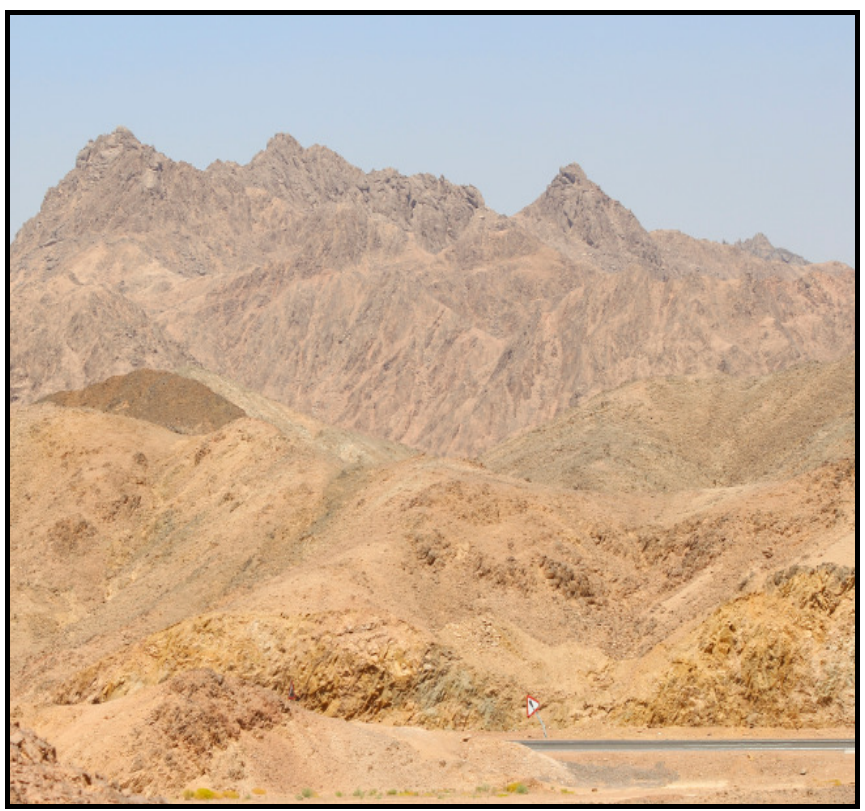

Plate 1. Wata Formation above the Raha Formation in Wadi Gharandal basin.

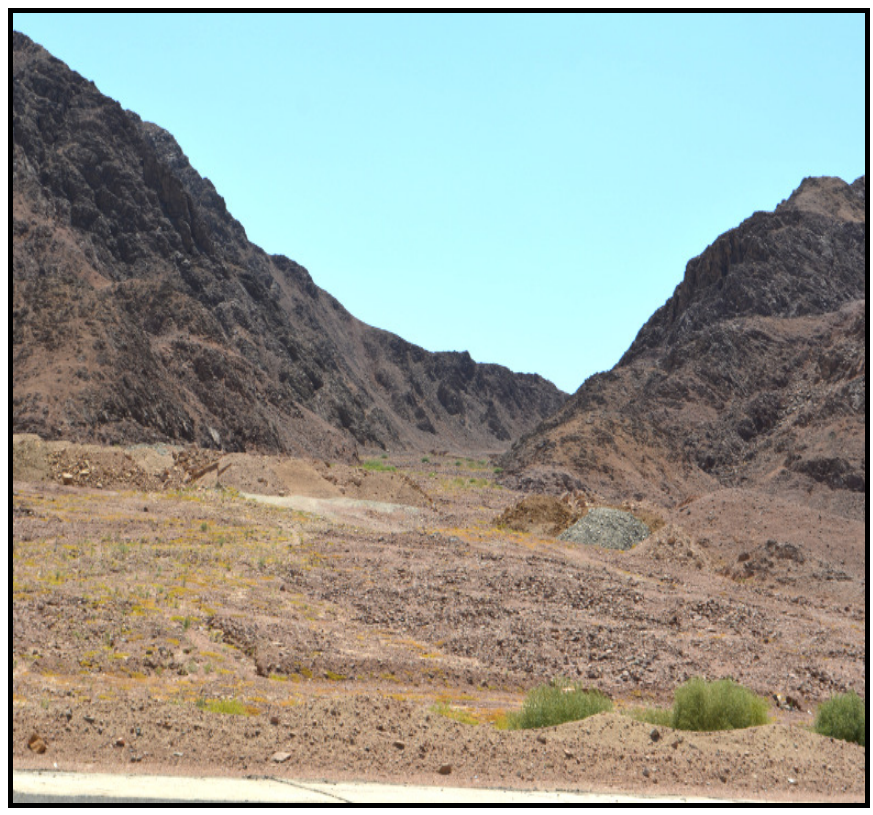

Plate 2. The Quaternary depositsare cover by the stmean courses and flood plainarea in Wadi Gharandal basin.

$-71-$ 
Table 1. Climatic Data of Three Meteorological Stations from 1980 up to 2016 for The study Area.

\begin{tabular}{|l|c|c|c|}
\hline \multicolumn{1}{|c|}{ Station } & $\begin{array}{c}\text { Saint } \\
\text { Catherine }\end{array}$ & EL-Tur & Ras Sudr \\
\hline Max T (C) & 24.3 & 28.3 & 28.7 \\
\hline Min T (C) & 8.9 & 17.5 & 17.6 \\
\hline Annual Rainfall & 63 & 10.4 & 15.4 \\
\hline Annual Rainfall in one day (mm/in2) & 10.5 & 6.2 & 3.4 \\
\hline Average evaporation (mm) & 11.6 & 9.9 & 8.8 \\
\hline Average Humidity (\%) & 29 & 59 & 58 \\
\hline
\end{tabular}

Source: The Egyptian meteorological authority from 1980 to 2016.

The minimum and maximum temperatures of the EL-Tur Station are 17.5$28.3{ }^{\circ} \mathrm{C}$ and for St. Catherine 8.9-24.3 ${ }^{\circ} \mathrm{C}$ and for Ras Sudr. 17.7-28.7 ${ }^{\circ} \mathrm{C}$. Flood resulting from convective rains has been observed during all seasons, the mean annual rainfall ranges between $10.4 \mathrm{~mm} /$ year at El Tur and $15.4 \mathrm{~mm} /$ year at Ras Sudr and $63 \mathrm{~mm} /$ year at St. Catherine and these amounts indicate that the rain increases toward the east of Sinai. The hydrographical basins of the study area which have high surface water potentialities due to the fact that the eastern branches of their steep sloping channels drain the high lands of south and central Sinai where high rates of rainfall prevail (Gad, 1996, P. 25).

However, chances for infiltration are limited due to the steep rocky slopes of their Wadis. Average rainfall is relatively low with a mean of about 3.4 $\mathrm{mm} /$ year at Ras Sudr Station, $6.2 \mathrm{~mm} /$ year El-Tur Station and relative humidity varies between 29 and 59\% at St. Catherine and El-Tur respectively. Evaporation in the study area is very important because it is much higher than precipitation; the values of evaporation depend on some factors such as temperature, relative humidity, wind speed, the plant cover and solar radiation and average evaporation varies between $8.8 \mathrm{~mm}$ Ras Sudr Station and 11.6 $\mathrm{mm}$ in St. Catherine.

Generally, the prevailing climatic conditions in the south Sinai include low rainfall, high temperatures, strong wind, high evaporation and low relative humidity.

\section{Morphometric Analysis of The studied Basin Using Satellite Image and GIS}

Combining the remote sensing data in terms of satellite images with topographic maps of smaller scale would noticeably enhance the accuracy of maps outputs. Overlying the automated networks on satellite images is considered as a good routine to enhance the accuracy of output networks and 
minimize the errors in the basin calculations. Another advantage of using the satellite images is getting high resolution and updated view of the drainage pattern (El-Behiry, 2005, p. 21). In the present study, the ASTER DEM data which corrected by topographic maps of scale 1:50,000 use the extract of the drainage networks of the study area. These work steps are indicated as follows:

a) In the frist step, a current of the stream network from the Digital Elevation Model (DEM). As shown in Figure (3), the stream network map of the Gharandal basin was extracted from this step. The extraction of the stream network was compared with parameters of a georeferenced topographic map $(1: 50,000)$, the Gharandal basin is of the sixth order according to ordering system of Strahler.

b) The water divide line was drawn through the highlands between the subbasins and matched with the topographic maps and then pour points were identified and digitized was used to ensure the accuracy of the work using the watershed tool.

c) Morphometric parameters for each part of the sub-basin were extracted in the GIS environment.

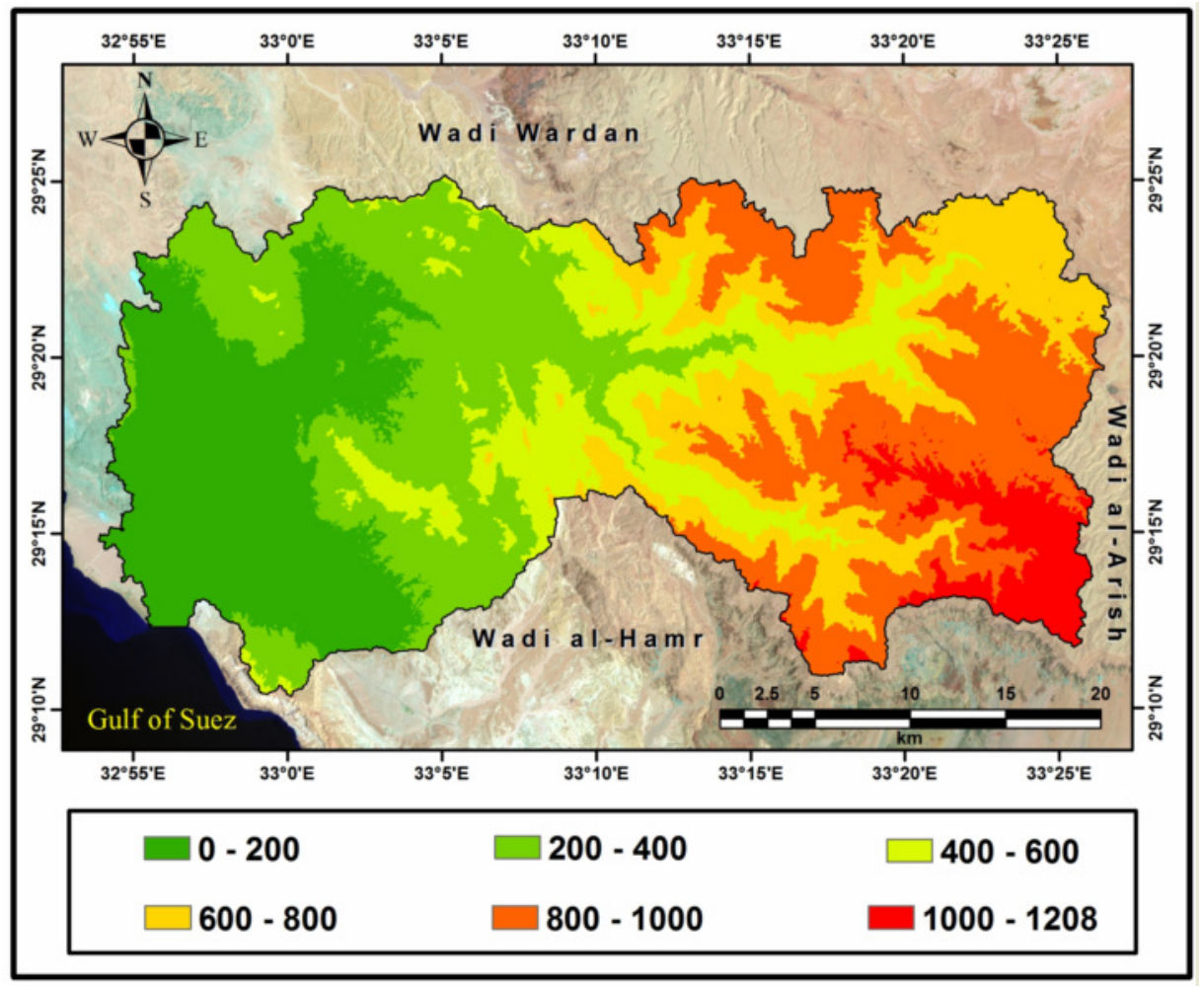

Figure 3. The digital elevation model (DEM) of the study area.

-73- 
The hydrographic Gharandal basin map that is delineated and divided into 18 sub-basins. Morphometric parameters of the drainage network were also computed using interactivity Arc GIS. The morphometric parameters with respect to the stream order (U), bifurcation ratio (RB), stream frequency (F), stream density (SD), and other morphometric parametric in (Table 2). The watersheds of the Wadi Gharandal basin are classified according to their area and the geomorphology characteristics for each watershed are used. The characteristics for each basin are summarized as the following:

Wadi Gharandal covers an area of about $1261.1 \mathrm{k} \mathrm{m}^{2}$ of which $74.6 \mathrm{~km}$ in length, the basin perimeter is about $223.5 \mathrm{~km}$, bifurcation ratio is 8.8 , frequency is 6.2. Wadi Gharandal has six order trunks that reflects the wide areal extent of the basin (Table 3), Wadi Gharandal is divided into eighteen relatively large sub-basin (Figure 4 and Table 2).

\section{Morphometric analysis of Hydrographic Gharandal Basins}

The hydrographic Gharandal basin that is delineated and divided into 18 sub-basins.

\section{Drainage Frequency (F):}

The high value of stream frequency is more than 0.5 and tend to give more possibilities for the collection of runoff. Drainage frequency in Wadi Gharandal basin, ranges between 3 in w (B6-5) sub-basin and $14.4 \mathrm{w}$ (B7-5) sub-basins.

\section{Overland Flow (OLF):}

Overland flow in wadi Gharandal ranges between 0.19 in w (B9-4) subbasin and 0.24 in w (B5-5) sub-basin. Generally, the basins of long overland flow make highly infiltration rate and also a low risk of flash floods.

\section{Drainage Density (CD):}

The drainage density is connected to rock strength erosion, to the climatic conditions and soil permeability. In geomorphology, the term density of fragmentation is utilised and is given by the report between the length of the valleys and the investigated surface, evaluated in the same measurement units (Filip, 2008). The basins of high values are a high flash flood and favored in regions of weak or impermeable surface material, Drainage density in Wadi Gharandal basin ranges between 1.6 in w (B12-4) sub-basin and 5.4 in w (B7-5) sub-basin (Table 2). 


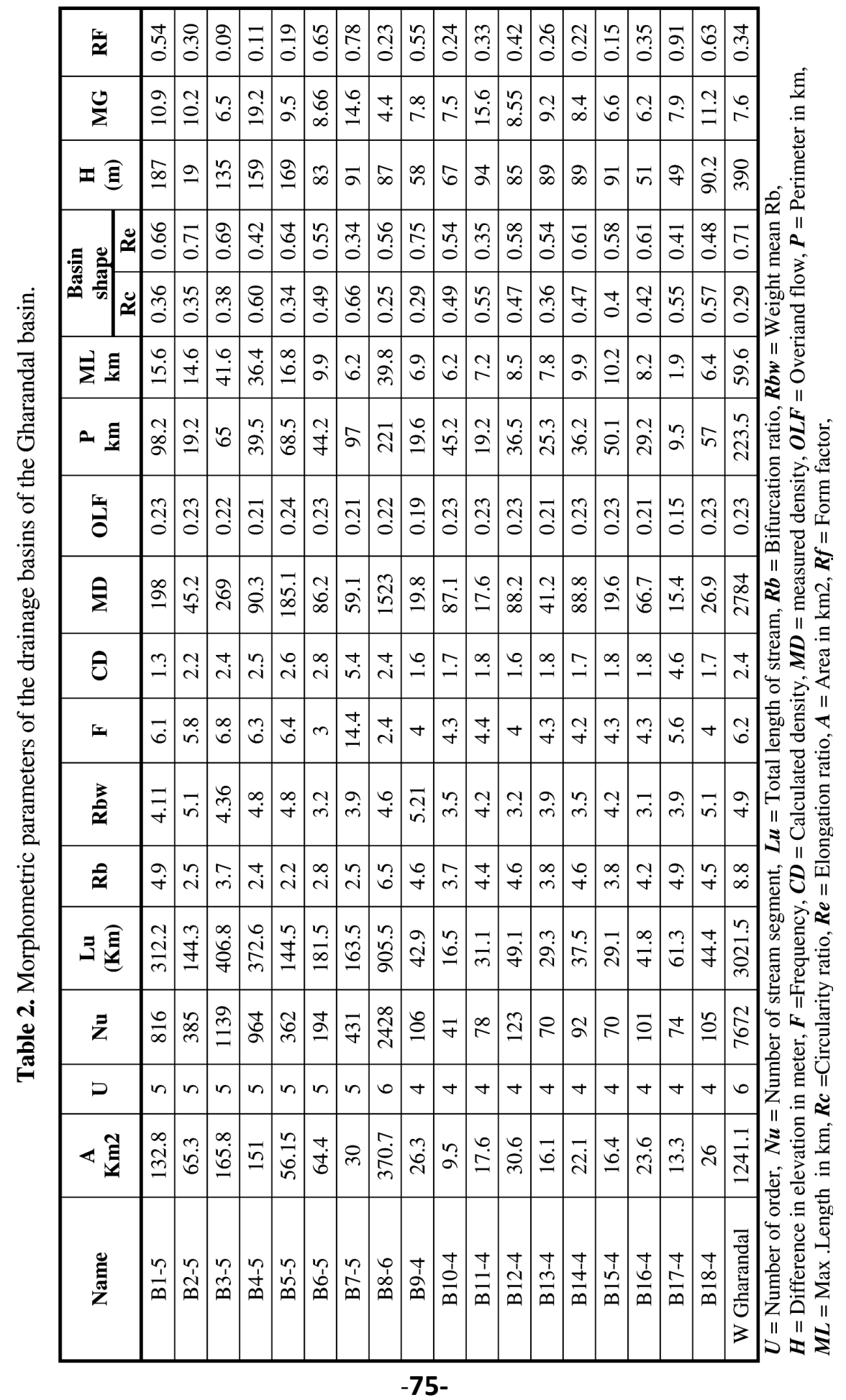




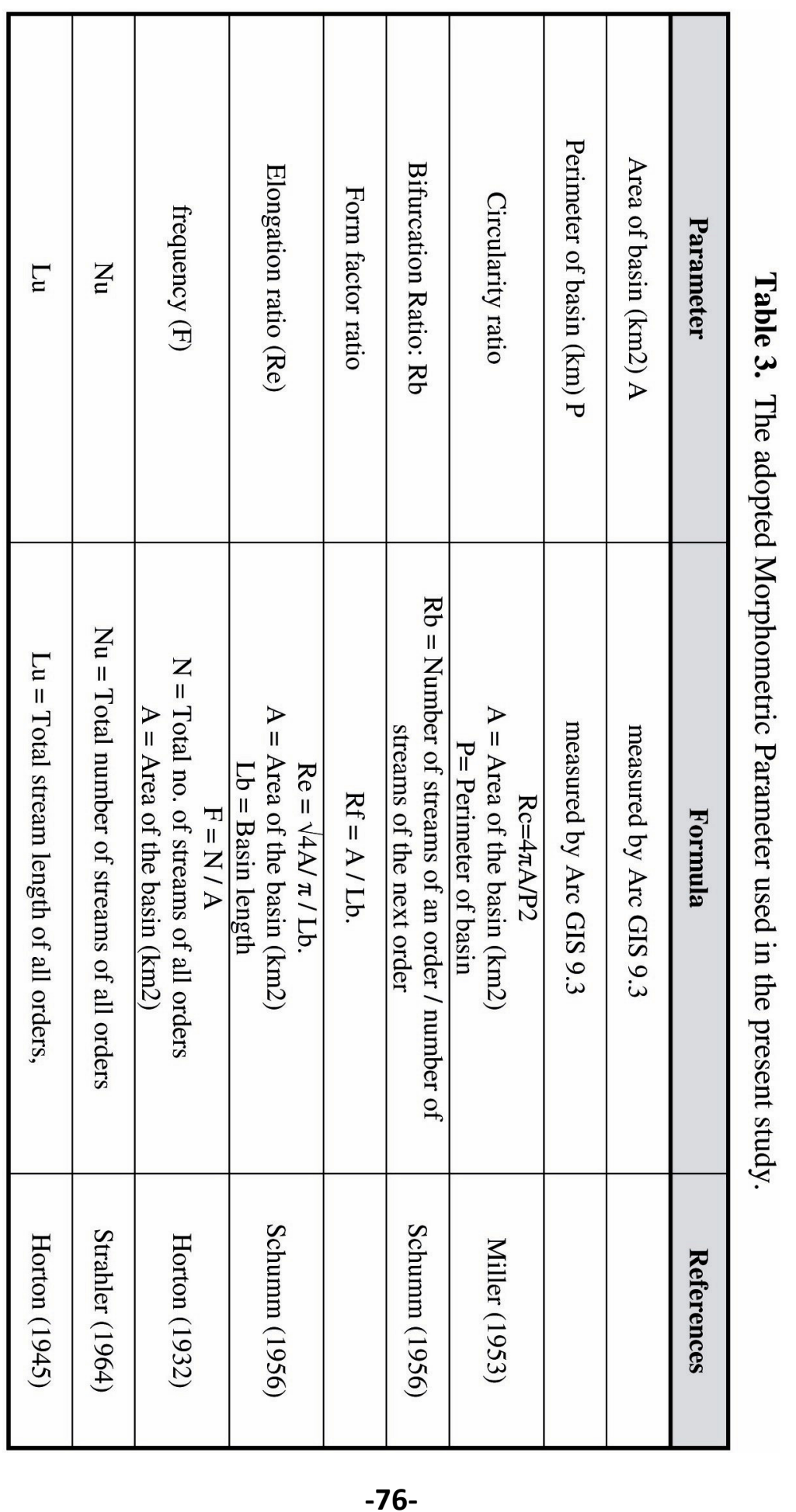




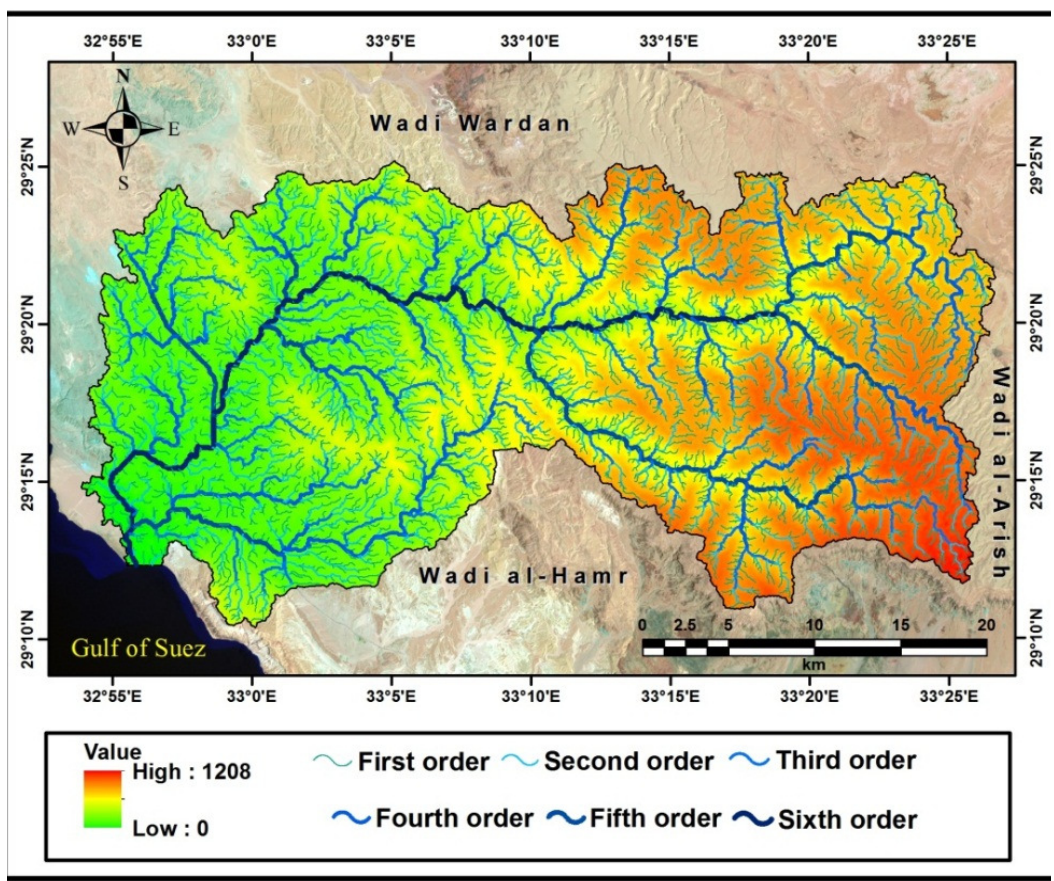

Figure 4. The drainage network Wadi Gharandal overlied of (DEM).

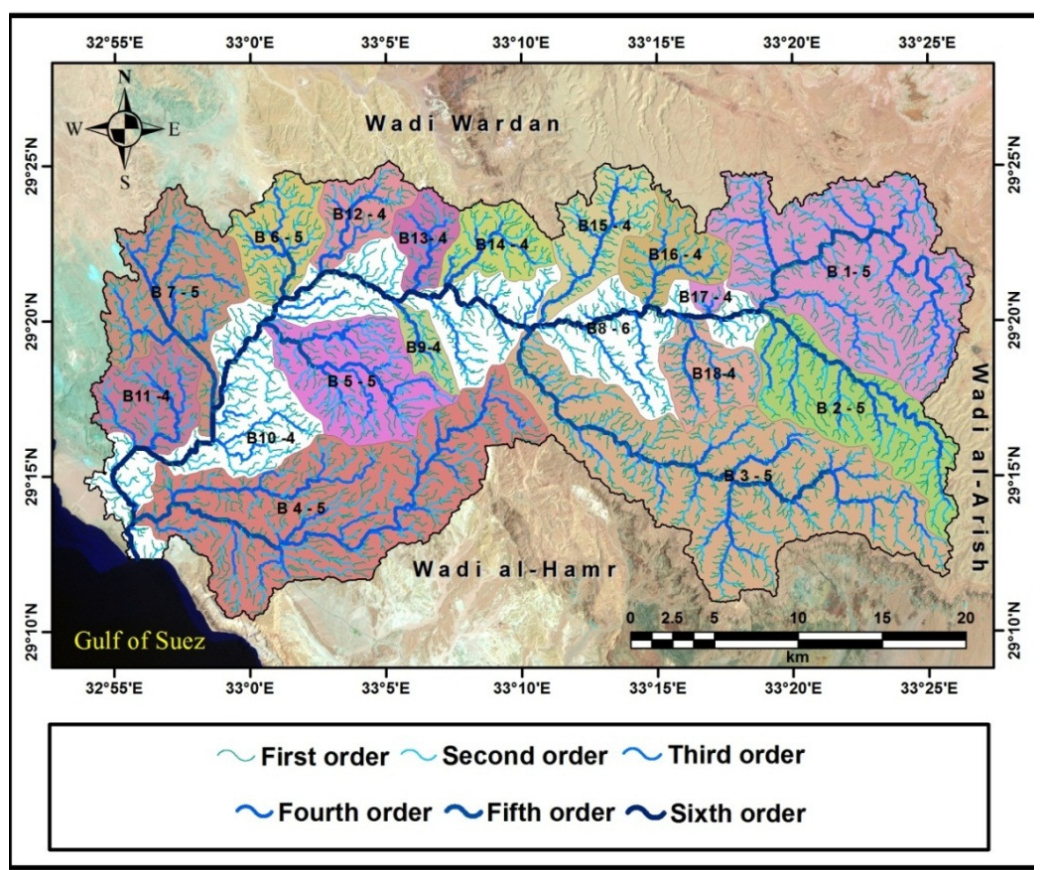

Figure 5. Wadi Gharandal basin and its sub basins.

-77- 


\section{Circularity Ratio (Rc):}

Circularity ratio near one is typical of regions of nearly circular basins with low relief and high-risk flash flood. In Wadi Gharandal basin, whereas the more values of circularity decrease the more a basin is far from regular shape the more circularity values increase, the more a basin is near of the regular shape. In the study area, w (B7-5) sub-basin is the nearest basin to regular shape while its values are considered the largst values reaching to 0.66 .

\section{Elongation Ratio (Re):}

The ratio between the diameter of circle with the same area of the basin (D) and the basin length (L). This ratio runs between 0.6 and 1.0 over a wide variety of climatic and geologic types. Values near to 1.0 are typical of regions of very low relief, whereas values in the range 0.6 to 0.8 are generally associated with hight relief and steep slopes (Strahler, 1964). Elongation ratio in Wadi Gharandal basin ranges between 0.71 in w (B2-5) sub-basin and 0.34 in (B7-5) sub-basin.

\section{Form Factor (RF):}

Factor as the ratio of the area of the basin and square of the basin length (Horton, 1932). Form factor in Wadi Gharandal basin 0.34, and ranges from 0.09 in w (B3-5) sub-basin to 0.91 in (B17-4) sub-basin.

\section{Mean Gradient (MG):}

A result to the slope of the basin affects mostly the quantity of infiltration that takes place and the rate of overland flow, the basins with time for infiltration and the recharge of groundwater is minimized (Arnous et al., 2011). Mean gradient in Wadi Gharandal basin ranges between 6.2 in $\mathrm{w}$ (B16-4) sub-basin and 19.2 in w (B3-5) sub-basin.

In the present study, ranking of streams has been carried out based on the method proposed by (Strahler, 1964). The stream orders are classified up to six orders in the Wadi Gharandal basin.

\section{Stream Number (Nu):}

The number of streams of different orders in a given drainage basin tends closely to approximate as inverse geometric series of which the first term is unity and the ratio is the bifurcation ratio (Horton, 1945). The total Stream number is 7655 stream lines including Wadi Gharandal basin is recognized in the whole basin, out of them $54.1 \%$ (4147) is $1^{\text {st }}$ order, $22.9 \%$ $(1753) 2^{\text {nd }}$ order, $10.8 \%(831) 3^{\text {rd }}$ order, $6.3 \%(304) 4^{\text {th }}$ order, $0.18 \%(24) 5^{\text {th }}$ order, $6^{\text {th }}$ order stream (1). 


\begin{tabular}{|c|c|c|c|c|c|c|c|c|c|c|c|c|c|c|c|c|c|c|c|c|c|}
\hline \multirow{3}{*}{$E_{0}$} & $\bar{\Xi}$ & & & & & & & & & $\Xi$ & & & & & & & & & & & A \\
\hline & $\Xi$ & & & & & & & & & $\stackrel{\text { Iִ }}{ }$ & & & & & & & & & & & $\stackrel{\text { I }}{-}$ \\
\hline & $\overline{\mathbf{z}}$ & & & & & & & & & - & & & & & & & & & & & - \\
\hline \multirow{3}{*}{ En } & $\bar{\Xi}$ & $\infty$ & $\hat{i}$ & $\overrightarrow{\text { in }}$ & $\hat{i}$ & 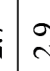 & & $m$ & $\overrightarrow{\mathrm{i}}$ & $\begin{array}{l}0 \\
0\end{array}$ & & & & & & & & & & & $\begin{array}{l}0 \\
\stackrel{i}{ }\end{array}$ \\
\hline & $\Xi$ & $n$ & $\stackrel{\infty}{\circ}$ & $\tilde{o}$ & $\stackrel{0}{0}$ & $\stackrel{\infty}{\infty}$ & & $n$ & $\stackrel{+}{0}$ & $\stackrel{?}{+}$ & & & & & & & & & & & $\begin{array}{l}0 \\
\infty\end{array}$ \\
\hline & $\bar{z}$ & - & - & - & - & - & & - & - & $=$ & & & & & & & & & & & ป \\
\hline \multirow{3}{*}{ 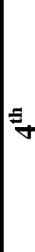 } & 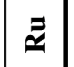 & $\infty$ & $\hat{i}$ & $\overrightarrow{\text { in }}$ & $\vec{i}$ & 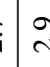 & & $m$ & $\vec{i}$ & $\stackrel{?}{\sim}$ & $m$ & $\mathrm{~N}$ & 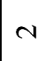 & in & F & 0 & $m$ & $\theta$ & in & $m$ & $\hat{i}$ \\
\hline & $\Xi$ & $\stackrel{\stackrel{m}{\sim}}{\stackrel{\sim}{*}}$ & 官 & $\stackrel{m}{\pi}$ & ळે. & ln & & $\stackrel{9}{-}$ & $\begin{array}{l}\infty \\
\stackrel{\Theta}{\mathrm{I}}\end{array}$ & $\left|\begin{array}{l}0 \\
\dot{0} \\
\dot{0}\end{array}\right|$ & 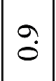 & $\begin{array}{l}0 \\
0\end{array}$ & $\stackrel{\infty}{0}$ & $\begin{array}{l}\infty \\
\dot{0}\end{array}$ & $\grave{0}$ & $\stackrel{\infty}{\infty}$ & $\dot{a}$ & $\grave{0}$ & $\begin{array}{l}\infty \\
\dot{0}\end{array}$ & $\stackrel{0}{\circ}$ & 竎 \\
\hline & $\bar{z}$ & $\cong$ & $n$ & $\ddot{\sim}$ & $\infty$ & $\exists$ & & 0 & $\curvearrowright$ & 志 & - & - & - & -1 & - & - & -7 & - & - & - & 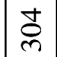 \\
\hline \multirow{3}{*}{$\bar{m}$} & $\vec{z}$ & $\stackrel{n}{-}$ & $\stackrel{\infty}{-}$ & $\tilde{i}$ & $\stackrel{m}{i}$ & $i$ & & $\begin{array}{l}\infty \\
i\end{array}$ & $\stackrel{\infty}{-}$ & $\stackrel{i}{i}$ & $\begin{array}{l}0 \\
\dot{+}\end{array}$ & $\stackrel{n}{i}$ & 6 & $\underset{\forall}{\stackrel{+}{*}}$ & $m$ & $\stackrel{\sim}{i}$ & $\nabla$ & $\stackrel{\curlyvee}{\dot{\gamma}}$ & $\begin{array}{c}\infty \\
\dot{m}\end{array}$ & in & $\bar{i}$ \\
\hline & $\Xi$ & $\begin{array}{l}\dot{0} \\
\infty \\
+\end{array}$ & $\stackrel{2}{I}$ & $\begin{array}{l}0 \\
\dot{y} \\
\dot{f}\end{array}$ & $\begin{array}{l}0 \\
\dot{m}\end{array}$ & : & & $\overrightarrow{0}$ & $\stackrel{m}{i}$ & $\begin{array}{l}\infty \\
\dot{ \pm} \\
=\end{array}$ & $\stackrel{\text { Iִ }}{=}$ & $\stackrel{0}{0}$ & $\stackrel{m}{0}$ & $\stackrel{n}{-}$ & $\stackrel{m}{i}$ & $\stackrel{a}{i}$ & $\stackrel{\infty}{\rightarrow}$ & $\vec{i}$ & $\vec{m}$ & $\vec{i}$ & $\underset{m}{\infty}$ \\
\hline & $\bar{z}$ & $\bar{\Xi}$ & $\stackrel{m}{q}$ & $\triangleq$ & $\stackrel{\varsigma}{\varrho}$ & $\bar{\gamma}$ & & 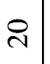 & in & 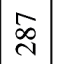 & $m$ & N & $N$ & in & 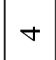 & 0 & $m$ & \% & in & $m$ & $\bar{\infty}$ \\
\hline \multirow{3}{*}{ 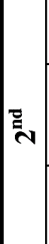 } & $\vec{z}$ & $\underset{\sim}{\sim}$ & $\underset{\sim}{\sim}$ & $\vec{i}$ & 9 & 0 & & $\exists$ & $\stackrel{\sim}{\sim}$ & $\vec{i}$ & ஸु & $\begin{array}{l}0 \\
0\end{array}$ & $\stackrel{\sim}{n}$ & $\stackrel{m}{+}$ & $\underset{+}{+}$ & $\begin{array}{l}n \\
n \\
n\end{array}$ & $\stackrel{n}{+}$ & $\nabla$ & $\begin{array}{l}0 \\
i\end{array}$ & $\stackrel{\leftrightarrow}{\dot{\gamma}}$ & $\underset{\dot{d}}{\stackrel{\Delta}{*}}$ \\
\hline & $\Xi$ & $\begin{array}{l}\underset{i}{i} \\
\stackrel{i}{n}\end{array}$ & 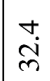 & Õ. & $\stackrel{\infty}{\circ}$ & $\begin{array}{l}c \\
\text { c }\end{array}$ & & 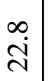 & $\begin{array}{l}0 \\
\stackrel{\text { }}{2}\end{array}$ & 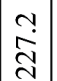 & $\begin{array}{l}0 \\
i \\
\text { in }\end{array}$ & $\overline{\mathrm{i}}$ & $\mid \begin{array}{l}\infty \\
\dot{f}\end{array}$ & $\begin{array}{l}\infty \\
\infty \\
\infty\end{array}$ & $\stackrel{\leftrightarrow}{\dot{\gamma}}$ & $n$ & $\begin{array}{l}\infty \\
\dot{+}\end{array}$ & $\underset{\infty}{\infty}$ & 永 & $\stackrel{9}{r}$ & ro \\
\hline & $\bar{z}$ & $\stackrel{\infty}{=}$ & $\bar{\infty}$ & $\stackrel{\overbrace{}}{\sim}$ & $\stackrel{\text { I }}{\text { r }}$ & 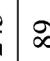 & & $n$ & 天े & $\begin{array}{l}\infty \\
:\end{array}$ & \pm & $n$ & $\simeq$ & $\tilde{a}$ & $\simeq$ & 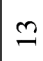 & $\simeq$ & $\approx$ & 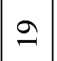 & $=$ & $\stackrel{\tilde{n}}{\Omega}$ \\
\hline \multirow{2}{*}{$\overrightarrow{\vec{n}_{1}}$} & $\Xi$ & \begin{tabular}{l}
\multirow{0}{0}{} \\
$\stackrel{0}{0}$
\end{tabular} & $\stackrel{\infty}{\curvearrowright}$ & ণ্ণি & $\begin{array}{l}\text { బิ } \\
\text { }\end{array}$ & $\begin{array}{l}n \\
\tilde{n}\end{array}$ & & ָ̊. & $\begin{array}{l}\overrightarrow{0} \\
\infty \\
\infty\end{array}$ & $\begin{array}{c}\vec{d} \\
\vec{j} \\
\dot{q}\end{array} \mid$ & $\begin{array}{l}\tilde{y} \\
\tilde{m}\end{array}$ & $\begin{array}{l}\tilde{y} \\
\ddot{g}\end{array}$ & 崩 & $\underset{m}{\infty}$ & $\frac{\sim}{\sim}$ & $\begin{array}{l}\infty \\
\infty \\
i\end{array}$ & $\mid \begin{array}{l}0 \\
\dot{\sim}\end{array}$ & $\begin{array}{l}\infty \\
\dot{m} \\
\dot{m}\end{array}$ & $\begin{array}{c}\tilde{y} \\
\tilde{f}\end{array}$ & $\begin{array}{l}0 \\
\dot{m}\end{array}$ & $\begin{array}{l}0 \\
\infty \\
0\end{array}$ \\
\hline & $\bar{z}$ & $\frac{0}{7}$ & $\stackrel{\sim}{\Omega}$ & in & $\mid \begin{array}{l}\infty \\
\stackrel{\infty}{q}\end{array}$ & $\underset{\infty}{\infty}$ & & $\stackrel{\circ}{\circ}$ & $\overline{\mathrm{d}}$ & $\overrightarrow{\widetilde{\Xi}}$ & $\begin{array}{l}\infty \\
\infty\end{array}$ & $m$ & $\hat{\sigma}$ & $\approx$ & $\ddot{n}$ & $\approx$ & 台 & $\approx$ & $\stackrel{q}{f}$ & 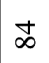 & $\frac{\gamma}{q}$ \\
\hline & 鸪 & $\frac{0}{\infty}$ & $\stackrel{\infty}{\infty}$ & $\stackrel{\vec{g}}{\exists}$ & ț & है & & 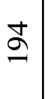 & $\overline{\widetilde{q}}$ & 文 & 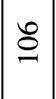 & $F$ & $\stackrel{\infty}{\sim}$ & $\tilde{\Xi}$ & $R$ & $\delta$ & 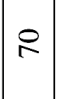 & 음 & i & $\stackrel{\varrho}{\varrho}$ & 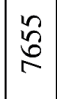 \\
\hline & 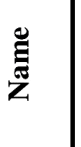 & $\frac{n}{\infty}$ & $\ddot{\sim}$ & $\tilde{m}$ & $\begin{array}{l}q \\
\dot{q} \\
m\end{array}$ & rn & & $\begin{array}{l}n \\
b \\
0\end{array}$ & $\frac{n}{\frac{1}{n}}$ & $\begin{array}{l}0 \\
0 \\
0 \\
\infty\end{array}$ & 官 & 满 & $\stackrel{ \pm}{\bar{m}}$ & $\begin{array}{l}\stackrel{+}{d} \\
\stackrel{m}{m}\end{array}$ & $\frac{\dot{J}}{\stackrel{m}{m}}$ & $\frac{j}{d}$ & 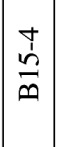 & $\begin{array}{l}\vec{t} \\
b \\
\ddot{n}\end{array}$ & 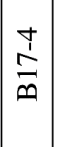 & $\begin{array}{l}+ \\
\stackrel{\infty}{\infty} \\
\frac{\infty}{m}\end{array}$ & \begin{tabular}{|l|}
$\overline{\bar{g}}$ \\
$\overline{\bar{z}}$ \\
$\overline{0}$ \\
3
\end{tabular} \\
\hline
\end{tabular}

$-79-$ 


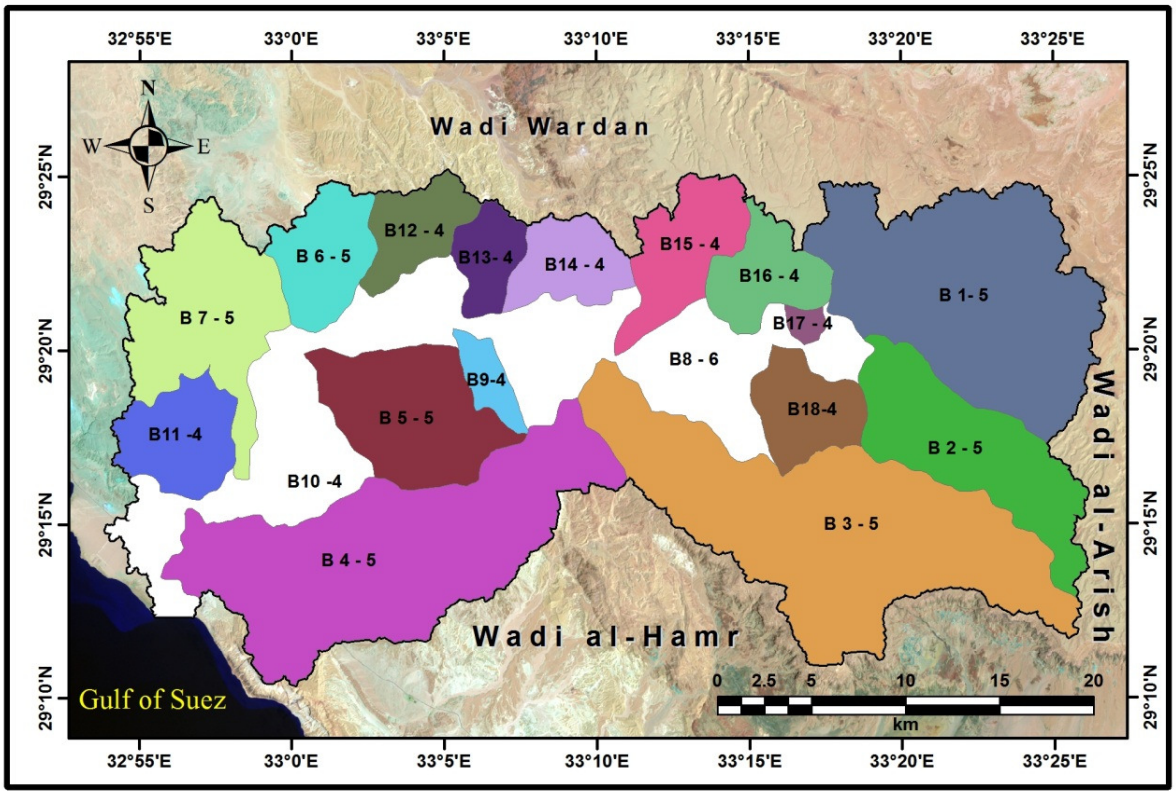

Figure 6. Grandell basin and its sub-basins in the study area.

\section{Stream Length (Lu):}

Stream lengths delineating the total lengths of stream segment of each of the successive orders in a basin tend to approximate a direct geometric series in which the first term is the average length of the stream of the first order. Horton (1945) identified that the cumulative stream length is higher in first-order streams and decreases as the stream order increases. The highest stream order $\left(6^{\text {th }}\right)$. Total stream length of all orders is $3133 \mathrm{~km}$ line of Wadi Gharandal basin is recognized in the whole basin, out of them $53.71 \%$ $(1685) \mathrm{km}$ is $1^{\text {st }}$ order, $22.2 \%(696.7) \mathrm{km} 2^{\text {nd }}$ order, $10.7 \%(338) \mathrm{km} 3^{\text {rd }}$ order, $12.9 \%(404.4) \mathrm{km} 4^{\text {th }}$ order, $0.27 \%(8.6) \mathrm{km} 5^{\text {th }}$ order, $0.03 \%(1.2) \mathrm{km}$ $6^{\text {th }}$ order.

\section{Shamy's Model:}

According to Shamy's Model, the area was divided into three areas: The first zone (A) is characterized by high possibility for flash floods and low possibility for the groundwater aquifer recharging, the second zone (B) is characterized by moderate possibility for flash floods and moderate possibility for recharging the groundwater aquifer, and the third zone (C) is characterized by less possibility for flash floods and high possibility for recharging the groundwater aquifer (Fouad, 2012) (Figure 7). 


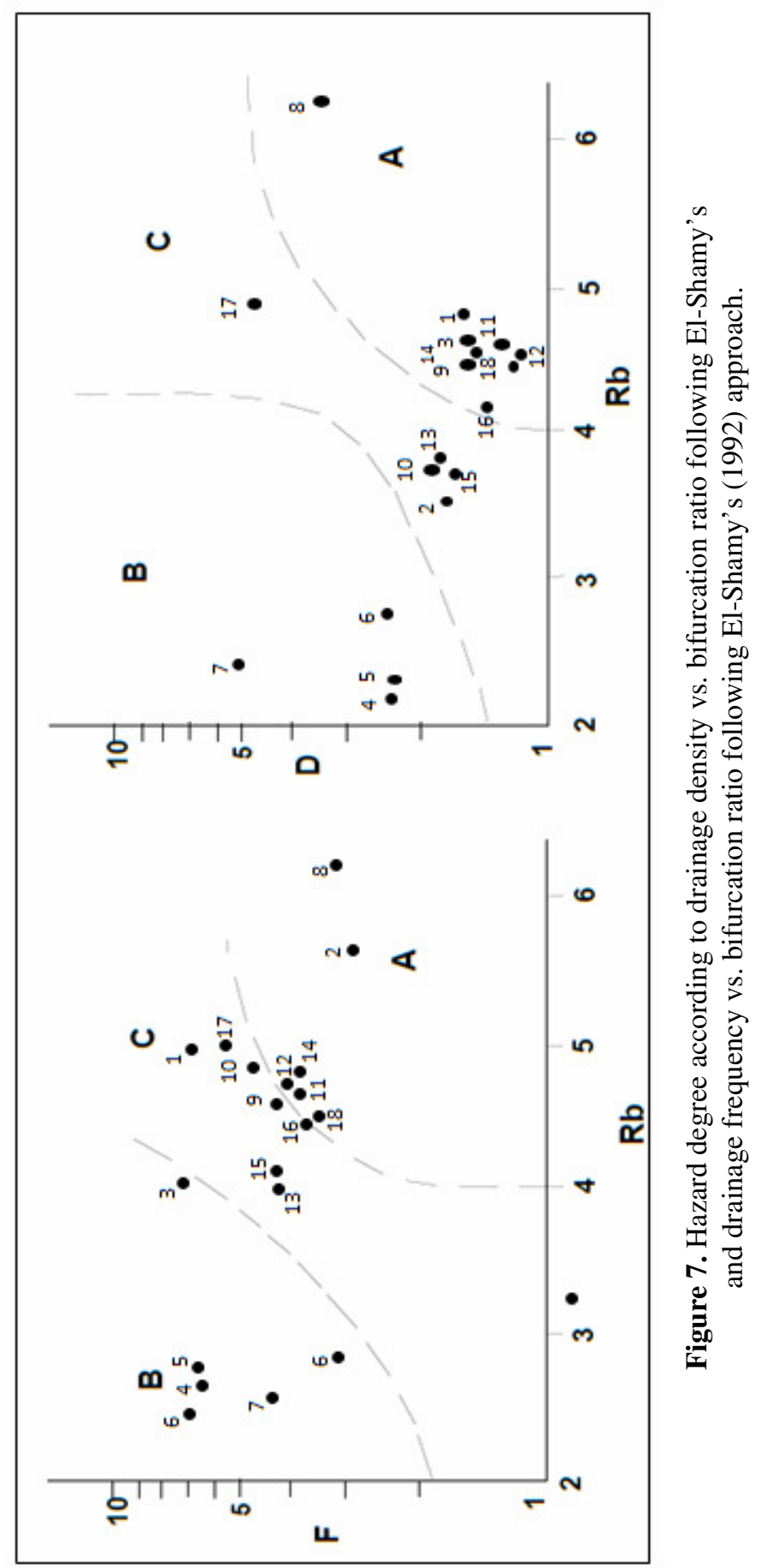

$-81-$ 
Table 5. Hazard degree analysis following El-Shamy's (1992) approach.

\begin{tabular}{|c|c|c|c|}
\hline Name & HD1 & HD2 & FHD \\
\hline B1-5 & M & H & H \\
\hline B2-5 & H & L & M \\
\hline B3-5 & L & H & H \\
\hline B4-5 & M & M & M \\
\hline B5-5 & M & M & M \\
\hline B6-5 & M & M & M \\
\hline B7-5 & M & M & M \\
\hline B9-4 & L & H & M \\
\hline B10-4 & L & H & M \\
\hline B11-4 & H & L & M \\
\hline B12-4 & H & H & H \\
\hline B13-4 & L & L & L \\
\hline B14-4 & H & H & H \\
\hline B15-4 & L & L & L \\
\hline B16-4 & H & H & H \\
\hline B17-4 & L & L & L \\
\hline B18-4 & H & H & H \\
\hline
\end{tabular}

HD1 = hazard degree Br vs. F, HD2 = hazard degree BR vs. D, and FHD = Final hazard degree from HD1 and HD2. L: low hazard (low possibility for flash floods); M: moderate hazard (moderate possibility for flash floods); and H: high hazard (high possibility for flash floods). (after: researcher based on Figure 7)

\section{1) Flash Flood Hazard Map}

According to the overlaying of all maps and calculation, the flash flood hazard map area definsd is shown in (Figure 6). The overall hazard degree was added to the GIS database to assist in constructing the drainage basin hazard map for the most hazardous basins. The assessment is based on the computed weight and mean values of the important morphometric parameters in Tables (6 and 7) consequently the study basin can be classified in accordance with the weighting process into three Catogeries: high, medium and low susceptibility for flooding shown in Table (7).

Finally, the Flash flood hazard map of Wadi Grandell basin is considered as a first atlempet to assess the hazadaurs zone in the whole basin and its sub-basin (Figure 8), and the results were indentical with El- Shamy's Model of six basins and deffered of three basins (Plate 3). 
The for ementioned assessment basically based on the morphometric parametcrs, therefor some field cheek and rainfall -runoff statistics are needed.

Table 6. The weighting ranges of the morphometric parameters.

\begin{tabular}{|l|c|c|c|}
\hline \multirow{2}{*}{ Flash flood scores based on } & \multicolumn{3}{c|}{ Measurer of drgrees hazard } \\
\cline { 2 - 4 } & $\mathbf{1}$ & $\mathbf{2}$ & $\mathbf{3}$ \\
\hline Area of basin (km2) A & $\leq 50$ & $50-100$ & $\geq 100$ \\
\hline Calculated density CD & $\geq 3$ & $2-3$ & $\leq 2$ \\
\hline Frequency F & $\geq 6$ & $6-4$ & $\leq 4$ \\
\hline Circularity ratio Rc & $\geq 0.3$ & $0.3-0.5$ & $\geq 0.5$ \\
\hline Overiand flow OLF & $\geq 0.23$ & $0.2-0.23$ & $\leq 0.20$ \\
\hline MG & $\leq 10$ & $10-20$ & $\geq 20$ \\
\hline Form factor RF & $\leq 0.3$ & $0.3-0.5$ & $\geq 0.5$ \\
\hline
\end{tabular}

Table 7. Flash flood hazard weight numbers for Gharandal sub-basins and total hazard socere for each one.

\begin{tabular}{|c|c|c|c|c|c|c|c|c|c|}
\hline \multirow{2}{*}{ Name } & \multirow{2}{*}{$\begin{array}{c}\text { Sub-basin } \\
\text { name }\end{array}$} & \multicolumn{7}{|c|}{ Flash flood scores based on } & \multirow{2}{*}{$\begin{array}{c}\text { Total } \\
\text { hazard } \\
\text { score }\end{array}$} \\
\hline & & $\mathbf{A}$ & CD & $\mathbf{F}$ & Rc & OLF & MG & RF & \\
\hline B1-5 & w. Abu Zerub & 3 & 3 & 3 & 1 & 1 & 2 & 3 & 16 \\
\hline B2-5 & w. Al-Muqar & 2 & 2 & 2 & 1 & 1 & 2 & 2 & 12 \\
\hline B3-5 & w. Abu Shuyukh & 3 & 2 & 3 & 1 & 2 & 1 & 1 & 13 \\
\hline B4-5 & w. Jaref & 2 & 2 & 3 & 3 & 2 & 2 & 1 & 15 \\
\hline B5-5 & w. Akhul & 2 & 2 & 3 & 1 & 1 & 1 & 1 & 11 \\
\hline B6-5 & w. Am Kathira & 2 & 2 & 1 & 2 & 1 & 1 & 3 & 12 \\
\hline B7-5 & w. Al'abyad & 1 & 1 & 3 & 3 & 2 & 2 & 3 & 15 \\
\hline B9-4 & w. Abu Nodah & 1 & 2 & 1 & 1 & 3 & 1 & 3 & 12 \\
\hline B10-4 & w. Am Kashem & 1 & 3 & 2 & 1 & 1 & 1 & 1 & 10 \\
\hline B11-4 & w. Alsulafa & 1 & 3 & 2 & 2 & 1 & 2 & 2 & 13 \\
\hline B12-4 & w. Abo Azzaz & 1 & 3 & 2 & 3 & 1 & 1 & 2 & 13 \\
\hline B13-4 & w. Laughed & 1 & 3 & 2 & 2 & 2 & 1 & 1 & 12 \\
\hline B14-4 & w. Al-Jabalah & 1 & 3 & 2 & 1 & 1 & 1 & 1 & 10 \\
\hline B15-4 & w. Hadib & 1 & 3 & 2 & 2 & 1 & 1 & 1 & 11 \\
\hline B16-4 & w. Abu Aalajah & 1 & 3 & 2 & 2 & 2 & 1 & 2 & 13 \\
\hline B17-4 & w. Azzaz & 1 & 1 & 2 & 3 & 3 & 1 & 3 & 14 \\
\hline B18-4 & w. Al-Asbaa & 1 & 2 & 2 & 3 & 1 & 2 & 3 & 14 \\
\hline
\end{tabular}

after: researcher based on Table (6). 
Table 8. Flash floods and ground water possibility of wadi Gharandal subbasins using some hydro-morphometric parameters.

\begin{tabular}{|l|c|c|}
\hline $\begin{array}{c}\text { high susceptibility } \\
\text { of flooding and low } \\
\text { water ground recharge } \\
\text { probability } \\
\leq \mathbf{1 3}\end{array}$ & $\begin{array}{c}\text { medium susceptibility } \\
\text { of flooding and medium } \\
\text { water ground recharge } \\
\text { probability } \\
\text { (11-13) }\end{array}$ & $\begin{array}{c}\text { low susceptibility } \\
\text { of flooding and high } \\
\text { water ground recharge } \\
\text { probability } \\
\mathbf{1 0}\end{array}$ \\
\hline B1-5 & B2-5 & B10-4 \\
\hline B3-5 & B5-5 & B14-4 \\
\hline B4-5 & B6-5 & \\
\hline B7-5 & B9-4 & \\
\hline B11-4 & B13-4 & \\
\hline B12-4 & B15-4 & \\
\hline B16-4 & & \\
\hline B17-4 & & \\
\hline B18-4 & & \\
\hline
\end{tabular}

after: researcher based on Table (7).

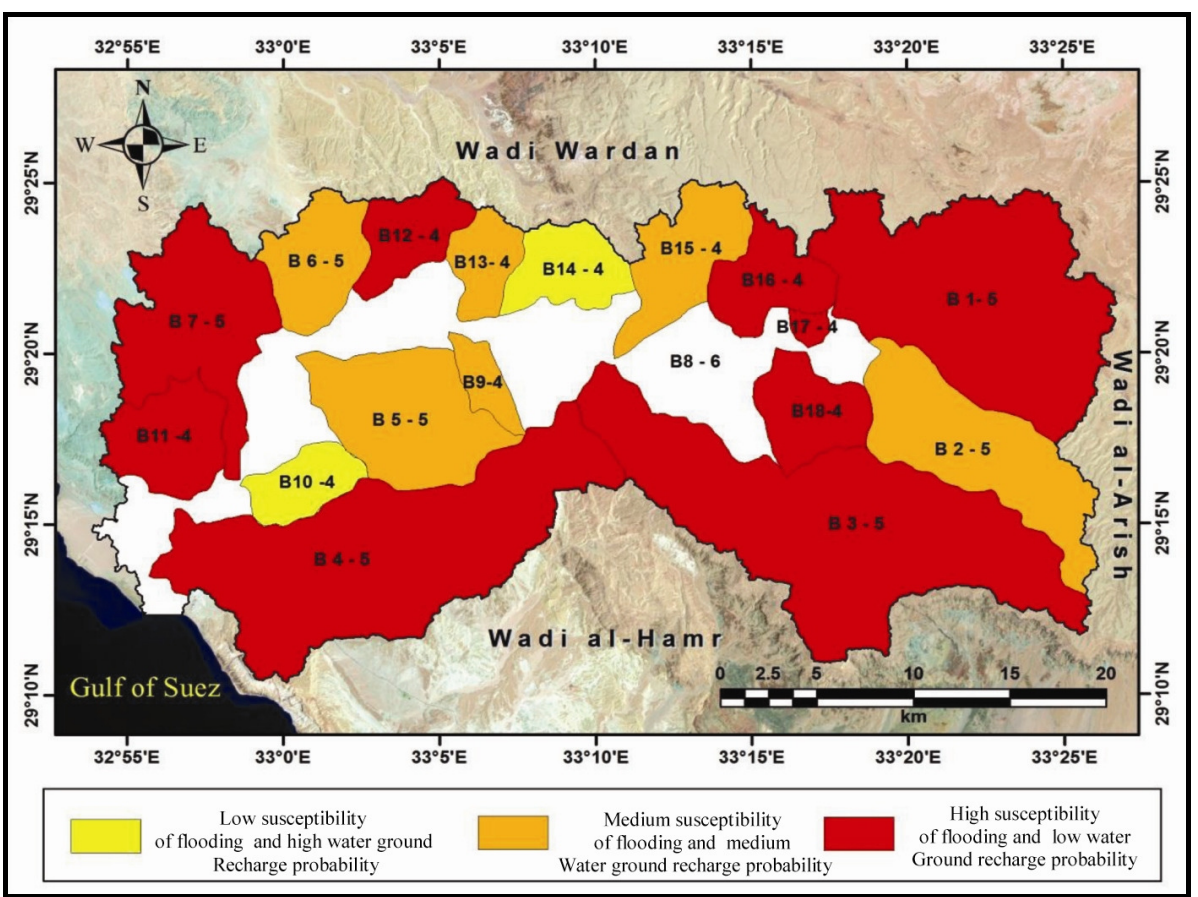

Figure 8. Flash flood hazard map of Wadi Gharandal basin sub-basins in the study area (based on the morphometric parameters). 


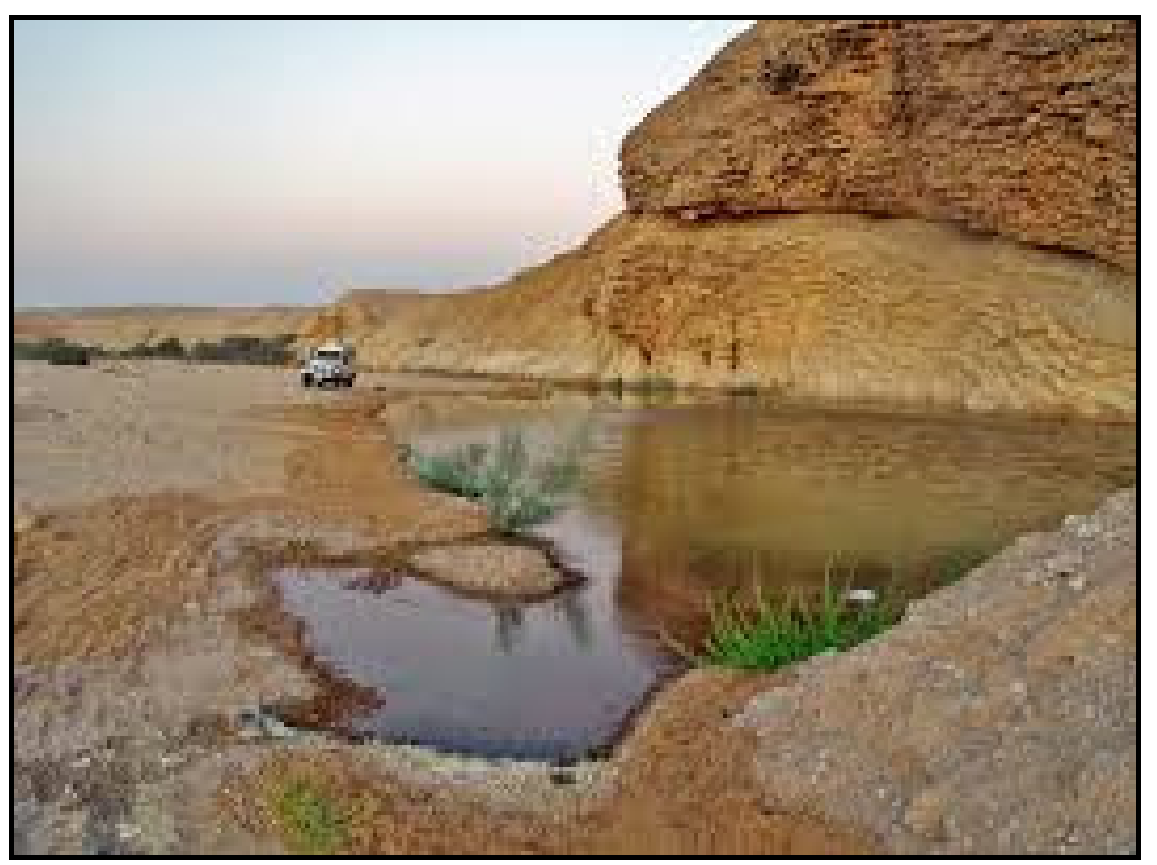

Plate 3. Cover of plant by flood waters wadi Gharandal basin.

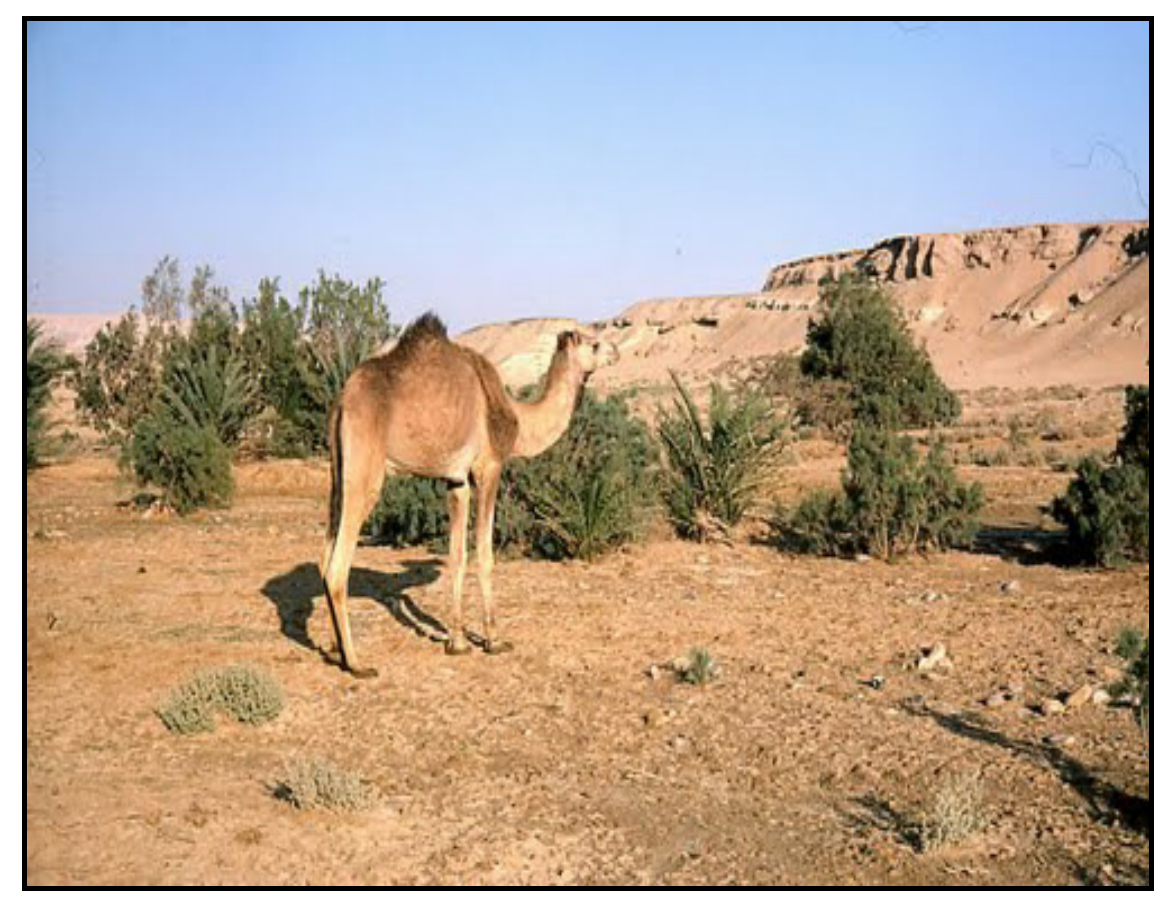

Plate 4. Flood waters wadi Gharandal basin.

$-85-$ 


\section{Conclusion}

A new framework which integrates the Geographic Information System (GIS) with the stallites images data for flood modeling developed. It also interconnects the terrain models and the GIS software.

The hydrographic basin of wadi Gharandal is divided into 18 delineated sub-basins. The morphometric parameters of wadi Gharandal are calculated. The flash hazard map of the area are caused mainly by soil and geological characteristic and morphometric parameters of the drainge basins. The flood hazard risk map of Wadi Gharandal basin shows that 53\% of the total subbasins in the Wadi Gharandal basin have a high flooding risk (Plate 4), and low water ground recharge probabilityAbout $35.3 \%$ of all sub-basins have medium flooding risk and medium water ground recharge probability, which includes the Gharandal sub-basin and $11.7 \%$ of the sub-basins have a low and high water ground recharge probability. These results can be used as basic data to assist flood mitigation and landuse planning of the flood plain of Wadi Gharandal area.

\section{References}

1. Anwar A. El-Fiky (2009): Hydrogeochemical Characteristics and Evolution of Groundwater at the Ras Sudr-Abu Zenima Area, Southwest Sinai, Egypt. Earth Sci., Vol. 21, No. 1, pp. 79-109.

2. Arnous, O., Aboulela, A. and Green, R. (2011): Geo-Environmental Hazards Assessment of the North Western Gulf of Suez, Egypt. Journal of Coastal Conservation, 15, 37-50.

3. Awis, Al Rashedi (1994): Wadi Gharandal Basin: A Geomorphogical study. Master, Faculty of Arts, Ain Shams University.

4. Conoco (1987): Geological Map of Egypt (scale 1: 500,000, NH 36 NE South Sinai and NH 36 SW Beni Suef).

5. Egyptian General Petroleum Corporation EGPC (1964): Oligocene and Miocene rock stratigraphyof the Gulf of Suez region. Report of the Stratigraphic Committee, $142 \mathrm{p}$.

6. El-Behiry M. G., A. Shedid A. Abu-Khadra, M. El-Huseiny (2005): Integrated GIS and Remote Sensing for Runoff Hazard Analysis in Ain Sukhna Industrial Area, Egypt. Earth. Sci., Vol. 15, pp. 17-42.

7. EL Shamy, I., (1992): Hydrogeologic assessment of Saint Catherine area, south Sinai. Geol. Sinai Develop., Ismailia, Egypt, pp. 71-76.

8. Fouad, M. Abd-ElAziz (2013): Geomorphological hazard map along southwestern sinia coast El-Tur area Using GIS, landscapes:perception, knowledge, awareness, and action, Addletion acaddletion Academic Publishers, Vol. 2, New York.

9. Fillip, S., (2008): Depresiunea şi munceii Băii Mari. Studiu de geomorfologie environmentală. Presa Universitară Clujană, Cluj-Napoca, 250 p. 
10. Gad MA (1996): Hydrology of wadies in Sinai. M.Sc. Thesis, Faculty of Science, Ain Shams University, Egypt.

11. Gawad, W.A., Gaafar, I. and Sabour, A.A. (1986). Miocene stratigraphic nomenclature in the Gulf of Suez region. Egyptian General Petroleum Corporation, $8^{\text {th }}$ Exploration Conference, pp. 1-20.

12. Horton, R.. (1932): Drainage basin characteristics. Trans. Amer. Geophys. Union, 13: 350-361.

13. Horton, R. (1945): Erosional development of streams and their drainage basins: Hydrological approach to quantitative morphology. Geological Society Bulletin, 56, pp. 275-370.

14. Issar A., Bein, A. and Michaell, A. (1972): On the ancient water of the upper Nubian Sandstone aquifer in central Sinai and southern Israel. Hydrogeol. J., 17: 353-374.

15. Jaban International Cooperation Agency, (JICA) (1999): South Sinai groundwater resources study in the Arab Republic of Egypt, main report, pacific consultations international, Tokyo in association with sandy consultation, Tokyo.

16. Miller, V.C. (1953): A quantitative geomorphic study of drainage basin characteristics in the Clinch Mountain area, Varginia and Tennessee. Project NR 389042, Tech. Rept. 3, Columbia University, Department of Geology, ONR, Geography Branch, New York.

17. Said, R. (1962): The Geology of Egypt. Elsevier, Amsterdam, p. 377.

18. Schumm, S. A. (1956), Evaluation of drainage systems and slopes in badlands at Perth Amboy, New Jersy. Bull. Geol. Soc. Amer, 67: 597-646.

19. Strahler, A.N. (1952): Hypsometric (Area-Altitude) Analysis of Erosional Topography, Geological Society of America Bulletin, Vol. 63, No. 11, pp. 1117-1142

20. Strahler, A.N. (1964): Quantitative geomorphology of drainage basins and channel networks. In: Handbook of Applied Hydrology, New York, McGraw Hill Book Company, Section 4II. 